\title{
Effect of the buffer system on stability of tetracaine hydrochloride $0.5 \%$ eyedrops
}

\author{
Emilija Fredro-Kumbaradzi ${ }^{*}$, Tanja Milenkoska², Marija Glavas-Dodov', Katerina Goracinova', \\ Kristina Mladenovska ${ }^{1}$
}

${ }^{1}$ Institute of Pharmaceutical Technology, Faculty of Pharmacy, .Ss.Cyril and Methodius University, Skopje

${ }^{2}$ Center for Military Health Services, Military Pharmacy, Skopje

Received October 2001; accepted April 2002

\begin{abstract}
The effect of the buffer system on the stability of tetracaine hydrochloride in eyedrop formulation was evaluated. Eyedrop formulations containing tetracaine hydrochloride $0.5 \%(\mathrm{w} / \mathrm{v})$ were prepared using different buffer systems (acetate, phosphate and borate buffer) under a constant $\mathrm{pH}$ of 5.4, and a buffer concentration of $0.06 \mathrm{M}$. Long-term tests at $26^{\circ} \mathrm{C}$ and accelerated stability tests at elevated temperature $\left(45,50,60{ }^{\circ} \mathrm{C}\right)$ over a period of 168 days were carried out by following the macroscopic view, $\mathrm{pH}$, sterility, content of tetracaine hydrochloride and detection of the degradation products. Also, values of the constant of degradation rate at different temperatures and $t_{90 \%}$ were calculated. The phosphate and acetate buffers provided satisfactory stability of tetracaine hydrochloride eyedrops, while borate buffer was not sufficient to maintain the $\mathrm{pH}$ value of the solution.
\end{abstract}

Key words: stability, tetracaine hydrochloride, eyedrops, buffer

\section{Introduction}

The estimation of stability is an important segment of the process of development of pharmaceutical dosage forms. The choice of optimal formulation is supported by good stability performance. Also stability tests are required for defining the expiry period and storage conditions $(1,2)$.

Tetracaine hydrochloride, as a local anaesthetic agent, is indicated in ophthalmology for diagnostic purposes as well as for surgery and post surgery treatment (3). Eyedrop formulations contain $0.25-1 \%(\mathrm{w} / \mathrm{v})$ of tetracaine hydrochloride in aqueous media. It should be prepared with respect of adjusting $\mathrm{pH}$.

The $\mathrm{pH}$ value is a critical formulation parameter not only because of the physiological tolerance of the eye (4), but also becouse of the pH-dependent stability of tetracaine hydrochloride $(5,6)$. Due to its ester structure, tetracaine hydrochloride is stable at a lower $\mathrm{pH}$ (7). As an ester-type compound, tetracaine hydrochloride undergoes hydrolysis, which results in the formation of n-buthyldimethylaminobenzoic acid and dimethylaminoethanol $(5,8,9)$.
Different buffer systems could be used for adjusting the $\mathrm{pH}$ value of aqueous solutions of tetracaine hydrochloride intended to be used as eyedrops in a range from 3.7 to 6.5 (5). Generally, the selection of buffer agent should be made with respect not only to adjusting and maintaining the $\mathrm{pH}$ of the solution, but also to the type and concentration of buffer agent. Since the hydrolytic degradation of the drug is acid and base catalysed, it is obvious that the buffer concentration should be kept as low as possible to diminish this catalytic effects $(1,10)$. Therefore, in the development stage of the liquid pharmaceutical dosage form, it is necessary to evaluate the stability of the drug substance in dosage form in terms of the catalytic effect of the buffer system. For this purpose, the drug degradation rate should be followed as a function of the type of buffer system in the formulation, while the $\mathrm{pH}$ and ionic strength are kept constant.

The aim of this study was to determine whether the type of buffer system (phosphate, acetate, and borate) affects the stability of tetracaine hydrochloride in $0.5 \%(\mathrm{w} / \mathrm{v})$ eyedrop formulation with pH 5.4 and a buffer concentration of $0.06 \mathrm{M}$.

*emfr@baba.ff.ukim.edu.mk 


\section{Experimental}

\section{Eyedrop formulation}

Eyedrops containing 0,5\% (w/v) tetracaine hydrochloride were prepared using different buffer systems: phosphate, acetate or borate (pH 5,4; 0,06M). Sodium chloride was used for isotonisation. No microbial preservative was added. Solutions were sterilised by use of bacteriological filtration. Formulations are given in table 1.

\section{Stability testing}

Long-term testing at $26^{\circ} \mathrm{C}$ (II climate zone ) (2) and short-term, accelerated tests at three elevated temperatures 45,50 and $60^{\circ} \mathrm{C}$ were used. Macroscopic evaluation (Ph.Eur.3), pH (Ph.Eur.3), sterility (Ph.Eur.3) and drug content (USP XX) were followed at certain time intervals over a period of 168 days. The obtained data were statistically processed. One way analysis of variance and the Scheffe method were used for processing of $\mathrm{pH}$ data. Rate constants of hydrolytic degradation of tetracaine hydrochloride at each temperature, the influence of temperature on the rate constant, as well as the $t_{90 \%}$ at $26{ }^{\circ} \mathrm{C}$ were estimated $(1,2)$ :

$$
\begin{aligned}
& \ln c=-k t+\ln c_{o} \\
& \ln k=\ln A-E a / R T \\
& t_{90 \%}=0.105 / k
\end{aligned}
$$

where

$$
\begin{aligned}
& c_{o} \text { - initial drug concentration }(t=0) \\
& c \text {-drug concentration at time } t \\
& k \text {-rate constant of the reaction of degradation (time }{ }^{-1} \text { ) } \\
& t \text { - time } \\
& A \text { - constant } \\
& E a-\text { activation energy } \\
& R \text { - gas constant } \\
& T \text { - absolute temperature } \\
& t_{90 \%} \text { - time required for degradation of } 10 \% \text { of drug. }
\end{aligned}
$$

In order to detect the degradation products, a HPLC method in accordance to the tetracaine hydrochloride eyedrops monograph (USPXXIII) was applied.

\section{Results and discussion}

Stability studies on prepared eyedrop formulations of tetracaine hydrochloride $0.5 \%(\mathrm{w} / \mathrm{v})$ indicated certain changes in the parameters followed.

The long-term study at $26{ }^{\circ} \mathrm{C}$, did not show any macroscopic change in all three eyedrops formulations over a period of 168 days. Exposure to an elevated temperature (accelerated stability

\begin{tabular}{|c|c|c|c|}
\hline \multirow[b]{2}{*}{ components } & \multicolumn{3}{|c|}{ formulation } \\
\hline & 1 & 2 & 3 \\
\hline tetracaine hydrochloride & $0.5 \mathrm{~g}$ & $0.5 \mathrm{~g}$ & $0.5 \mathrm{~g}$ \\
\hline sodium chloride & $0.471 \mathrm{~g}$ & $0.479 \mathrm{~g}$ & $0.617 \mathrm{~g}$ \\
\hline \multicolumn{4}{|c|}{ phosphate buffer $0.06 \mathrm{M}$, pH 5.4 ad 100ml } \\
\hline acetate buffer 0.06 M, pH 5.4 & & ad $100 \mathrm{ml}$ & \\
\hline borate buffer $\quad 0.06 \mathrm{M} \mathrm{pH} 5.4$ & & & ad $100 \mathrm{ml}$ \\
\hline
\end{tabular}
tests) caused very slight red-brownish colouring of the solutions (table 2). The coloration of formulation 1, containing phosphate buffer, was registered after 84 days of storage at $50{ }^{\circ} \mathrm{C}$ and 56 days at $60^{\circ} \mathrm{C}$, while in the presence of acetate buffer it was noticed after 56 days $\left(45^{\circ} \mathrm{C}\right), 28$ days $\left(50^{\circ} \mathrm{C}\right)$ or 14 days $\left(60^{\circ} \mathrm{C}\right)$. Formulation 3 , prepared using a borate buffer, showed slight coloration only at the highest temperature of $60{ }^{\circ} \mathrm{C}$ after 56 days. The red-brown colour is probably a result of decomposition of n-buthylaminobenzoic acid, induced by extreme temperature $(5,11)$.

The follow up of the $\mathrm{pH}$ value is an important parameter

Table 1. Tetracaine hydrochloride eyedrop formulations

since the decomposition of tetracaine hydrochloride results in $\mathrm{pH}$ decrease. Table 3 shows the statistical parameters obtained from $\mathrm{pH}$ data by use of one way analysis of variance and the Scheffe method. A statistically significant change of $\mathrm{pH}$ value within a storage period of 168 days at $26^{\circ} \mathrm{C}$ was registered only in the eyedrop solution containing borate buffer. Exposure to an elevated temperature facilitated the $\mathrm{pH}$ changes in all samples. During the accelerated stability tests, acetate buffer provided the most stable pH value. Taking into consideration the corresponding buffer capacities of the three buffer systems used (table 4), the $0.06 \mathrm{M}$ borate buffer has a very low buffer capacity $\left(10^{-6} \mathrm{M} \mathrm{HCl}\right)$, while the same molarity of acetate or phosphate buffer provides higher buffer capacities $\left(10^{-2}\right.$ and $10^{-4} \mathrm{M} \mathrm{HCl}$ respectively). Therefore, an acetate buffer enables the most efficient maintaining of the $\mathrm{pH}$ value, while the buffer capacity of borate buffer was insufficient.

Changes in the content of tetracaine $\mathrm{HCl}$ during the stability testing is presented in figure 1 . Table 5 shows the rate constants of hydrolytic degradation of tetracaine hydrochloride at each temperature, as well as the $t_{90 \%}$ at $26^{\circ} \mathrm{C}$.

As can be seen, the slowest rate of hydrolytic degradation at each temperature occurred in the sample containing borate buffer (table 5). The time required for degradation of $10 \%$ of drug substance $\left(\mathrm{t}_{90 \%}\right)$ at $26^{\circ} \mathrm{C}$ was 318 days. This could be explained by: (a) an insufficient buffer capacity of borate buffer (table 4) that allowed a decrease of $\mathrm{pH}$ value and (b), an increased stability of tetracaine hydrochloride at a lower $\mathrm{pH}$ on the other hand. The stability of tetracaine hydrochloride in formulations containing phosphate and acetate buffer is similar 
Table 2. Macroscopic changes of samples 1-3 exposed to different temperatures

\begin{tabular}{lccccccccccccc}
\hline \hline temperature & $26{ }^{\circ} \mathrm{C}$ & \multicolumn{1}{c}{$45^{\circ} \mathrm{C}$} & \multicolumn{4}{c}{$50{ }^{\circ} \mathrm{C}$} & \multicolumn{2}{c}{$60{ }^{\circ} \mathrm{C}$} \\
\hline time (days) & $0-168$ & 0 & 28 & 56 & 84 & 0 & 28 & 56 & 84 & 0 & 14 & 28 & 56 \\
\hline sample 1 & - & - & - & - & - & - & - & - & + & - & - & - & + \\
sample 2 & - & - & - & + & + & - & + & + & + & - & + \\
sample 3 & - & - & - & - & - & - & - & - & - & - & - & - & + \\
\hline
\end{tabular}

+ macroscopic changes - no changes

Table 3. Statistical analysis of $\mathrm{pH}$ value data - one way analysis of variance and Scheffe method

\begin{tabular}{|c|c|c|c|c|c|c|c|}
\hline \multicolumn{8}{|c|}{$26{ }^{\circ} \mathrm{C}$} \\
\hline sample & $\mathrm{F}_{\mathrm{t}}$ & $\mathrm{F}$ & \multicolumn{4}{|c|}{ F-ratio for } & $\mathrm{F}^{\prime}$ \\
\hline & & & $\mathrm{X}_{0}$ and $\mathrm{X}_{28}$ & $\mathrm{X}_{0}$ and $\mathrm{X}_{56}$ & $\mathrm{X}_{0}$ and $\mathrm{X}_{84}$ & $\mathrm{X}_{0}$ and $\mathrm{X}_{168}$ & \\
\hline 1 & & 3.46 & - & - & - & - & \\
\hline 2 & 3.48 & 3.37 & - & - & - & - & 13.92 \\
\hline 3 & & 113.82 & 9.64 & 17.14 & 213.34 & 289.74 & \\
\hline \multicolumn{8}{|c|}{$45^{\circ} \mathrm{C}$} \\
\hline sample & $\mathrm{F}_{\mathrm{t}}$ & $\mathrm{F}$ & & \multicolumn{3}{|c|}{ F-ratio for } & $F^{\prime}$ \\
\hline & & & & $\mathrm{X}_{0}$ and $\mathrm{X}_{28}$ & $\mathrm{X}_{0}$ and $\mathrm{X}_{56}$ & $\mathrm{X}_{0}$ and $\mathrm{X}_{84}$ & \\
\hline 1 & & 116.48 & & 31.50 & 87.60 & 330.30 & \\
\hline 2 & 4.07 & 5.19 & & 5.13 & 10.05 & 13.13 & 12.21 \\
\hline 3 & & 173.05 & & 217.56 & 342.25 & 425.39 & \\
\hline \multicolumn{8}{|c|}{$50{ }^{\circ} \mathrm{C}$} \\
\hline sample & $\mathrm{F}_{\mathrm{t}}$ & F & & \multicolumn{3}{|c|}{ F-ratio for } & $\mathrm{F}^{\prime}$ \\
\hline & & & & $\mathrm{X}_{0}$ and $\mathrm{X}_{28}$ & $\mathrm{X}_{0}$ and $\mathrm{X}_{56}$ & $\mathrm{X}_{0}$ and $\mathrm{X}_{84}$ & \\
\hline 1 & & 73.79 & & 46.88 & 142.24 & 181.51 & \\
\hline 2 & 4.07 & 18.47 & & 8.96 & 26.74 & 50.07 & 12.21 \\
\hline 3 & & 209.93 & & 244.45 & 412.58 & 522.16 & \\
\hline \multicolumn{8}{|c|}{$60^{\circ} \mathrm{C}$} \\
\hline sample & $\mathrm{F}_{\mathrm{t}}$ & $\mathrm{F}$ & & \multicolumn{3}{|c|}{ F-ratio for } & $F^{\prime}$ \\
\hline & & & & $\mathrm{X}_{0}$ and $\mathrm{X}_{14}$ & $\mathrm{X}_{0}$ and $\mathrm{X}_{28}$ & $\mathrm{X}_{0}$ and $\mathrm{X}_{56}$ & \\
\hline 1 & & 110.82 & & 129.94 & 211.76 & 280.06 & \\
\hline 2 & 4.07 & 22.58 & & 11.88 & 32.06 & 62.06 & 12.21 \\
\hline 3 & & 287.90 & & 330.67 & 599.76 & 689.05 & \\
\hline
\end{tabular}

( $\mathrm{t}_{90 \%}$ on $26^{\circ} \mathrm{C}$ was 181 and 157 days respectively). The degradation rate constant $k$ versus temperature plots for all three formulations are shown comparatively in figure 2 . A significant increase in the degradation rate by increasing the temperature is obvious. For phosphate and acetate buffer, by increasing the temperature, $\mathrm{k}$ values $\left(\right.$ day $\left.^{-1}\right)$ have been changed from $10^{-4}$ order $\left(26^{\circ} \mathrm{C}\right)$ to $10^{-2}\left(60^{\circ} \mathrm{C}\right)$.

In order to register the products of degradation of tetracaine hydrochloride, HPLC studies were carried out. A decrease of the
Table 4. Calculated values of buffer capacities

\begin{tabular}{ll}
\hline \hline buffer & $\beta_{\text {for acid }}(\mathrm{M} \mathrm{HCl})$ \\
\hline phosphate buffer $(0.06 \mathrm{M} \mathrm{pH} 5.4)$ & $8.41 \times 10^{-4}$ \\
acetate buffer $(0.06 \mathrm{M} \mathrm{pH} 5.4)$ & $3.05 \times 10^{-2}$ \\
borate buffer $(0.06 \mathrm{M} \mathrm{pH} \mathrm{5.4)}$ & $7.74 \times 10^{-6}$ \\
\hline
\end{tabular}

Table 5. Degradation rate constant $(\mathrm{k})$ and $\mathrm{t}_{90 \%}$ of tetracaine hydrochloride in eyedrop formulations 1-3 at different temperatures

\begin{tabular}{|c|c|c|c|c|c|c|c|c|}
\hline \multirow[t]{2}{*}{ Sample } & \multicolumn{4}{|c|}{$\mathrm{k}\left(\right.$ day $\left.^{-1}\right)$} & \multicolumn{4}{|c|}{$\mathrm{t}_{90 \%}$ (days) } \\
\hline & $26^{\circ} \mathrm{C}$ & $45^{\circ} \mathrm{C}$ & $50^{\circ} \mathrm{C}$ & $60^{\circ} \mathrm{C}$ & $26^{\circ} \mathrm{C}$ & $45^{\circ} \mathrm{C}$ & $50^{\circ} \mathrm{C}$ & $60^{\circ} \mathrm{C}$ \\
\hline 1 & $5.80 \cdot 10^{-4}$ & $3.31 \cdot 10^{-3}$ & $4.63 \cdot 10^{-3}$ & $1.51 \cdot 10^{-2}$ & 181 & 31.7 & 22.7 & 6.9 \\
\hline 2 & $6.70 \cdot 10^{-4}$ & $4.60 \cdot 10^{-3}$ & $6.84 \cdot 10^{-3}$ & $2.04 \cdot 10^{-2}$ & 157 & 22.8 & 15.3 & 5.1 \\
\hline 3 & $3.30 \cdot 10^{-4}$ & $1.18 \cdot 10^{-3}$ & $1.98 \cdot 10^{-3}$ & $4.07 \cdot 10^{-3}$ & 318 & 89.0 & 53.0 & 25.8 \\
\hline
\end{tabular}

Макед. фарм. билт., 47, (1,2) 15-20 (2001) 
tetracaine hydrochloride quantity in aged samples was accompanied by the appearance of two new peaks in all three formulations. Figure 3 represents comparatively the HPLC chromatograms of sample 1 freshly prepared (a), stored for 56 days at $60{ }^{\circ} \mathrm{C}$ (b) and standard of PABA (c). Comparison of the chromatograms clearly indicates a decrease in the concentration of tetracaine hydrochloride (retention time $\mathrm{Rt}_{1} 4.33 \pm 0.03$ ) during ageing and the appearance of two new peaks in aged samples $\left(\mathrm{Rt}_{2}\right.$ 2.42 $\pm 0.02 ; \mathrm{Rt}_{3} 3.12 \pm 0.01$ ), which could be related to the degradation products $(5,9)$. Since the retention time of standard of PABA (2.41 \pm 0.01$)$, proposed as a standard for the detection of related substances (BP99, Tetracaine hydrochloride eyedrops

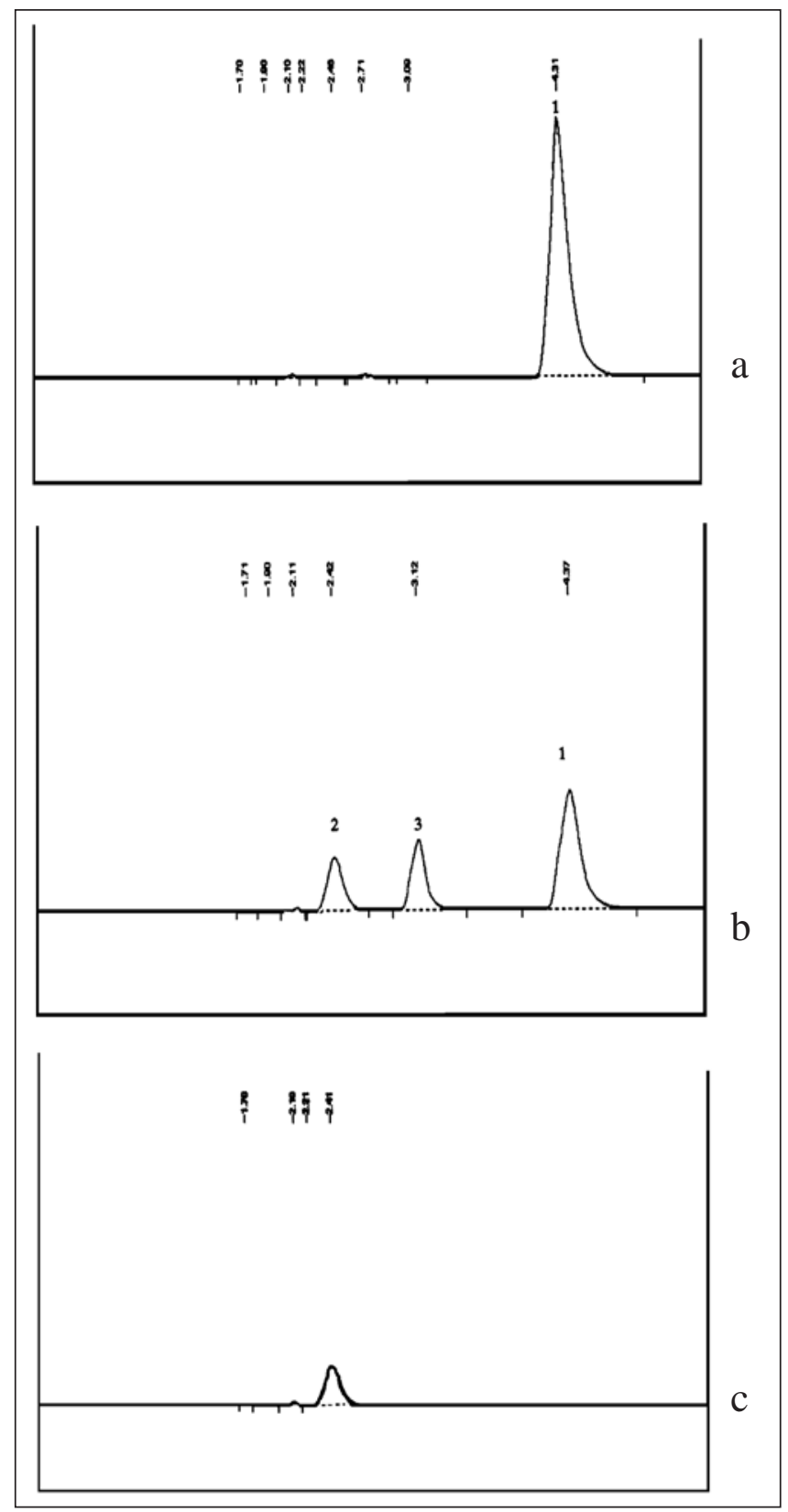

Fig 3. HPLC chromatograms of sample 1: freshly prepared (a), stored for 56 days at $60{ }^{\circ} \mathrm{C}$ (b)a nd standard of PABA (c).
Sample 1

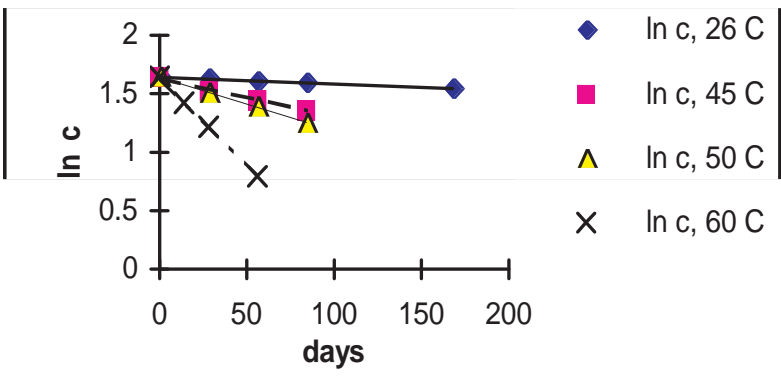

Sample 2

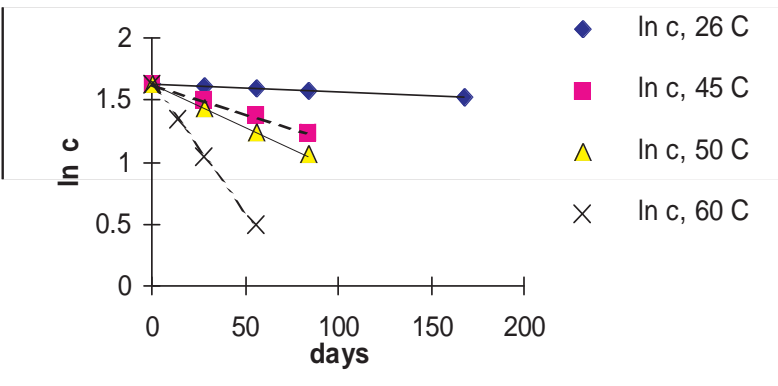

Sample 3

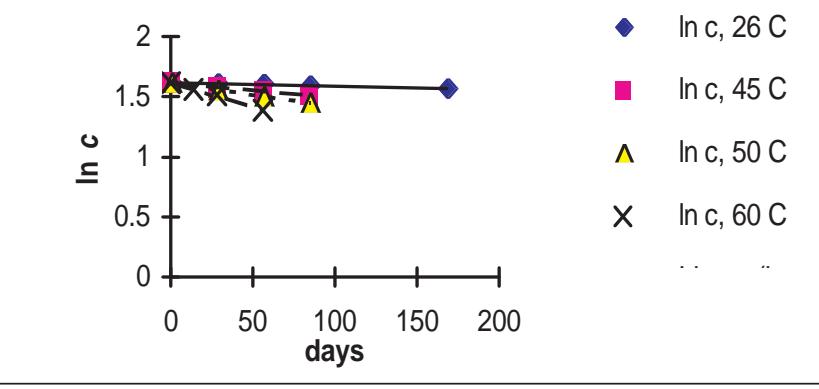

Fig 1. In c ( $\mathrm{n}=3$ ) versus time plots of samples 1-3 at different temperatures

monograph), corresponds to $\mathrm{Rt}_{2}$, this peak is related to the n-buthyldimethylaminobenzoic acid.

Regarding the sterility of eyedrop solutions, all three samples remain sterile within a stability testing period of 168 days.

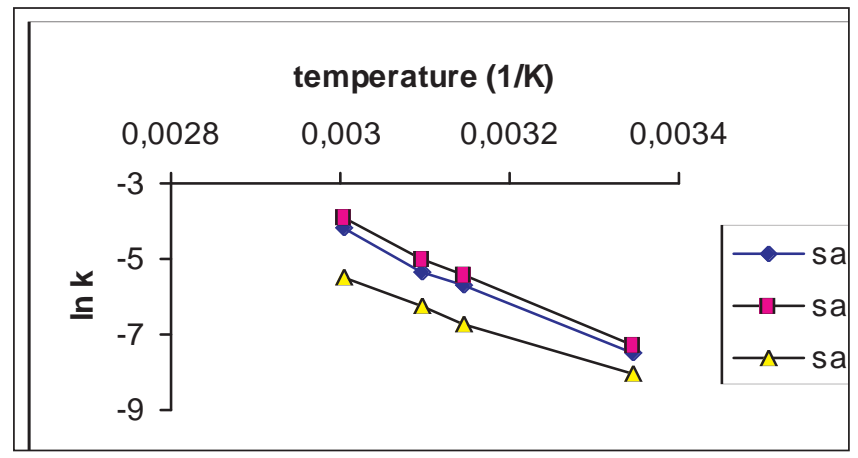

Fig 2. Arrhenius plot for three formulations of tetracaine hydrochloride $0,5 \%$ eyedrops 


\section{Conclusion}

The stability of the tetracaine $0,5 \%(\mathrm{w} / \mathrm{v})$ eyedrop solution with $\mathrm{pH} 5,4$ and a constant buffer concentration of $0.06 \mathrm{M}$ is a function of the buffer system used in formulation. Incorporation of a phosphate or acetate buffer $0.06 \mathrm{M}$ with $\mathrm{pH}$ 5.4 in formulation of $0,5 \%(\mathrm{w} / \mathrm{v})$ tetracaine hydrochloride eyedrops provided satisfactory stability ( $\mathrm{t}_{90 \%} 181$ and 157 days respectively). Although the degradation rate of tetracaine hydrochloride in the formulation containing $0,06 \mathrm{M}$ of borate buffer was twice as slow ( $\mathrm{t}_{90 \%} 318$ days), this formulation is not acceptable because its poor buffer capacity was insufficient to maintain the $\mathrm{pH}$ value.

\section{References}

1. J. Carstensen, Drug Stability, Marcel Dekker, New York,1990

2. W. Grimm, G.Schepky, Stabilitatpufung in der Pharmazie, Theorie und Praxis, Ed. Cantor Aulendorf, 1980.

3. USP Drug Information for the Health Care Professionals, vol.1, 16th ed., US Pharmacopeial Convention Inc 1997.

4. K.E. Avis, H.A.Lieberman and L.Lachman, Ed., PharmaceuticaL Dosage Forms, Parenteral Medications, Marcel Dekker, New York, 1992.

5. R. Dolder and F.Skinner, Ophtalmica, Wissenschaftliche Verlagsgesellschaft $\mathrm{mbH}$, Stuttgart 1990

6. D.B. Kersten and B.Gober,U.Tim,Pharmazie 36,341(1981)

7. B. Gober, U.Timm and S.Pfeifer, Pharmazie 34 (3),161-164 (1979)

8. J. Breinlich, Pharm..Ztg.110, 579 (1965)

9. G.N. Menon and B.J.Norris, J.Pharm.Sci., 70(5),569-570 (1981)

10. L. Lachman, H.A. Lieberman and J. Kanig, Ed.,The Theory and Practice of Industrial Pharmacy, Lea \&Febiger, Philadelphia, 1970.

11. W. Lund, Ed., The Pharmaceutical Codex, 12th ed.,The Pharmaceutical Press, London, 1994.

\title{
Резиме
}

\section{Ефект на пуферскиот систем врз стабилноста на капки за очи со $0,5 \%$ тетракаин хидрохлорид}

\author{
Емилија Фредро-Кумбараџи ${ }^{1}$, Тања Миленкоска², Марија Главаш-Додов ${ }^{1}$, Катерина Горачинова $^{1}$ \\ Кристина Младеновска ${ }^{1}$

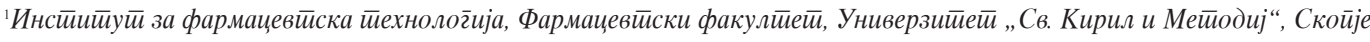 \\ ${ }^{2}$ Воена айиека, Ценйар за военоздравстивени услуг̄и, Скойје
}

\section{Клучни зборови: стабилност, тетракаин хидрохлорид, очни капки, пуфер}

Испитуван е ефектот на пуферскиот систем врз стабилноста на тетракаин хидрохлоридот во очни капки. Приготвени се три формулации на очни капки со 0,5\% тетракаин хидрохлорид во кои е употребен различен пуфер (фосфатен, ацетатен или боратен) во концентрација 0,06М и рН вредност 5,4. Стабилноста е испитувана со примена на долготрајни тестови $\left(26{ }^{\circ} \mathrm{C}\right)$ и забрзани тестови за следење на стабилноста $\left(45,50,60{ }^{\circ} \mathrm{C}\right)$ во тек на период од 168 дена. Следени се параметрите: макроскопски изглед, рН содржина на тетракаин хидрохлорид и деградациони продукти и стерилност. Определени се константите на брзина на разградба на тетракаин хидрохлоридот на различни температури, како и времето на разград-

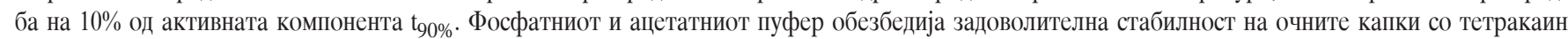
хидрохлорид, додека боратниот пуфер поради нискиот пуферски капацитет не беше во можност да ја одржи рН вредноста на капките за очи. 